\title{
Towards An Appropriate Construction Industry Resource Levelling Model for Kenya
}

\author{
Case Study of Insitu Concrete Works by Registered Construction Firms in Nairobi \\ County.
}

\author{
Absalom Habil Lamka ${ }^{1}$ \\ Department of Construction Economics \& Mgt, TUK, \\ Nairobi, Kenya.
}

\author{
Professor, Sylvester Munguti Masu² \\ Department of Construction Economics \& Mgt, TUK, \\ Nairobi, Kenya.
}

\author{
Dr. Githae Wanyona ${ }^{3}$ \\ Department of Construction Management, JKUAT, \\ Nairobi, Kenya.
}

\begin{abstract}
The under- performance of construction firms in Kenya has generated a lot of concern to the clients in the industry. Delivery of constructed facility within the predetermined duration, budgeted cost and stipulated quality specifications has remained a mirage to many construction firms. These concerns have exerted formidable pressure to construction firms to be more effective in terms of better utilization of resources. Lack of a predictive assessment model on performance with regard to resource utilization of construction firms in Kenya has made planning of resources a problem. The purpose of the study is to evaluate the impacts of resource levelling practices on performance of construction firms' in Kenya and propose a predictive assessment model which would lead to improved resource utilization. In the study, key performance indicators that are; time, cost, quality, coupled with effective resource management on construction sites were identified through intensive literature search.

The research design used in the study was of the mixed approach. The study targeted 143 participants from National Construction Authority (NCA) registered contractors. Stratified sampling technique was used in quantitative data collection and purposive sampling for qualitative interviews. The data analysis procedure adopted was: the descriptive statistics, correlation analysis, statistical package for social sciences (SPSS) version 21 and Microsoft Excel 2010 software.

The findings from this study ranked financial control, optimization of resources and competence of supervisors as the factors with the greatest impact on performance with respect to resource utilization. The study further established an assessment model for resource levelling that reduces undesirable resource fluctuation and enhances construction firms' performance.

The study therefore recommends that construction firms should employ competent supervisors and provide them with continuous training opportunities in the fields of financial control and optimization of resources so as to enhance performance.
\end{abstract}

Keywords: Construction firms, resources, resource levelling, performance, fluctuations.

\section{INTRODUCTION}

\section{A. Background}

The construction industry is defined as 'that sector involved with design, erection, repair and demolition of buildings and civil engineering works in an economy' (Mbiti, 2008). Globally, the industry utilizes resources which encompass labour, plant, materials, finance, time and space to deliver the constructed physical facilities to the clients. To meet the physical limits of construction resources, to avoid day-to-day fluctuation in resource demands and to maintain an even flow of application for construction resources, resource levelling is needed in the construction industry. The management technique which attempts to minimize the fluctuation in requirements by optimizing the use of resources to project activities in a manner that will improve productivity and performance is known as resource levelling (Harington, 2007). Traditional resource levelling models assume activity durations to be deterministic (Inuwa, 2014). Nevertheless, activity duration may be uncertain, owing to variations in the overall environment, such as weather, site congestion and productivity levels.

In a developing country like Kenya where there has been increased investment in infrastructure development, construction projects have advanced in complexity due to the increasing uncertainties in technology, budgets, development processes and resource recruitment. The output of the Kenya construction industry rose to $13.9 \%$ in 2015 compared to $13.1 \%$ in 2014 (KNBS, 2016). This arose from the construction activities of the Mombasa - Nairobi Standard Gauge Railway (SGR), expansion of major airports, roads, energy infrastructure and refurbishment of road networks (KNBS, 2016). The need to optimize resources in Kenya so as to achieve desired results within the set time frame and budget is critical for projects performance.

Resource fluctuations on constructions sites are of a great concern to the parties in the construction industry as it affects site performance (El-Rayes, 2009). Undesirable resource fluctuation affects the overall project performance and 
productivity levels. High resource peak demand causes congestion problems on site. Activities have to wait for the resources resulting in poor productivity and increased project cost. In order to minimize those negative impacts on project performance, there is a pressing need for developing robust models that are capable of eliminating undesirable resource fluctuations.

\section{B. Research Problem}

Lack of appropriate resource levelling management tools for use by construction firms in Kenya has made planning of resources unpredictable and thereby influencing overall construction project performance (Gwaya, 2015). Advancement in complexity of construction projects has exerted formidable challenges in resources utilization as the resources need to be well managed in order to reduce the inherent uncertainty in balancing demand for resources with the available supply (PMI, 2015). Resources fluctuation beyond acceptable limits is bad for employee morale as it negatively affects crew efficiency, team spirit and leads to poor project performance. The network programming methods in existence are not responsive to the need of the field personnel as they are too dependent on specialists for implementation and don't depict resource utilization (Galloway, 2006). Despite the previous studies in Kenya on project performance and the application of existing resource utilization techniques notably by Talukhaba (1999), Gichunge (2000), Wanyona (2005),Masu (2006), Muchungu (2012) and Gwaya (2015) among others, the problem of fluctuation in resources on construction sites has remained un-resolved to contractors in their predictive resource levelling practices. The aforementioned researchers established that time and cost performance of projects in Kenya escalated to the extent that over $70 \%$ of the projects initiated were likely to extend in time with a magnitude of over $50 \%$, while over $50 \%$ of the projects were likely to increase in cost with a magnitude of over $20 \%$.

\section{Research objectives}

The main objective of the study was to evaluate the impacts and benefits of resource levelling management practices on performance with regard to resource utilization of construction firms' in Kenya and propose a possible assessment model which would lead to improved performance in resource utilization. The case study of in-situ concrete works by construction firms' in Nairobi County was considered under the survey.

\section{Study Significance}

The findings would be valuable in the construction industry as they will prioritize the influence of resource levelling prediction on performance with regard to resource utilization. This would assist the contractors to minimize undesirable resource fluctuation and improve performance in resource utilization practice in project delivery in Kenya. Further, the developed assessment model for resource levelling management practice from the research provides a measure for performance on resource utilization which will contribute to the existing body of knowledge, as well as improving decision making skills for policy makers and thereby contributing towards improved performance by construction firms.

\section{RESOURCE UTILIZATION STUDIES}

\section{A. Project performance and Implementation}

Construction projects are generally unique and are built on sites using a couple of resources that encompass labour, plant, materials, finance, time and space among others (Chitkara, 2012). The need for effective management of resources to deliver the constructed facility to the client within the predetermined duration, budgeted cost and stipulated quality specifications is crucial for project performance and implementation. El-Rayes (2009) argues that each project will need a different blend of quality and quantity of resources to achieve specified performance objectives. Project management requires exactness and the determination of resources for a project should be correctly ascertained. Excessive fluctuations in construction activity bring about uncertainty in construction business and consequently harm the construction industry as firms would have to adjust resource levels in line with the available work at various stages in the workload cycle.

Construction projects require a high level of quality control of resources for its successful delivery. The study by Masu (2006) showed that in developing countries, finance resource and machine time combination accounted for $86.0 \%$ of the causes of poor performance in projects. A work plan, prepared prior to the commencement of construction works in a project, would therefore, be instrumental in formulating directions, coordinating functions, setting targets, forecasting resources, budgeting costs, controlling performance and motivating people

\section{B. Resource levelling}

This is defined by a Guide to the Project Management Body of Knowledge (PMBOK Guide) as "a technique in which start and finish dates are adjusted based on resource constraints with the goal of balancing demand for resources with the available supply (PMI, 2015).There would be reallocation of total or free slack in activities to minimize fluctuation in the resource requirement profile while maintaining the original project completion time. Resource levelling involves the delay of non-critical activities within their total float limits and manipulations of the daily resource requirements. The thinking behind resource levelling is the establishment of schedules in which resources become as level as possible without changing the original completion time of the project, the aim being to reduce the peaks and troughs associated with resources requirements in a project (Chitkara, 2012).This would be more efficient because every upswing has a cost impact whether it comes from bringing new crew to the site of the project or procuring more equipment. The costs of learning on the job can be exorbitant as they arise from problems of logistics, teamwork and site safety issues.

\section{Tools for assessment of performance}

In the construction industry, work study technique has been used quite often as an assessment tool in determining the success in productivity performance. The aim of work study is the provision of data to assist management in making decisions and to enable them to utilize with maximum efficiency all available resources by applying a systematic approach to situations being reviewed as opposed to intuitive 
guesswork (ILO, 1996-2016). The two main work study techniques used in the construction industry for resource utilization are method study and work measurement. The principal techniques by which work measurement is carried out in the case study of in-situ concrete works include; time study, activity sampling, synthesis from synthetic data, and analytical estimating (Forster, 2014).

\section{Conceptual framework}

In order to improve performance of construction firms, there was need to investigate the factors that impacts on construction resource leveling practice. Presented in figure 1 is the conceptual framework for the study showing how construction resource levelling (dependent variable) will be affected by six independent variables of construction project performance. The factors affecting resource levelling and performance were obtained from literature search from Gwaya (2015), PMI, (2015) and Masu (2006) among others researchers earlier mentioned

Dependent variable

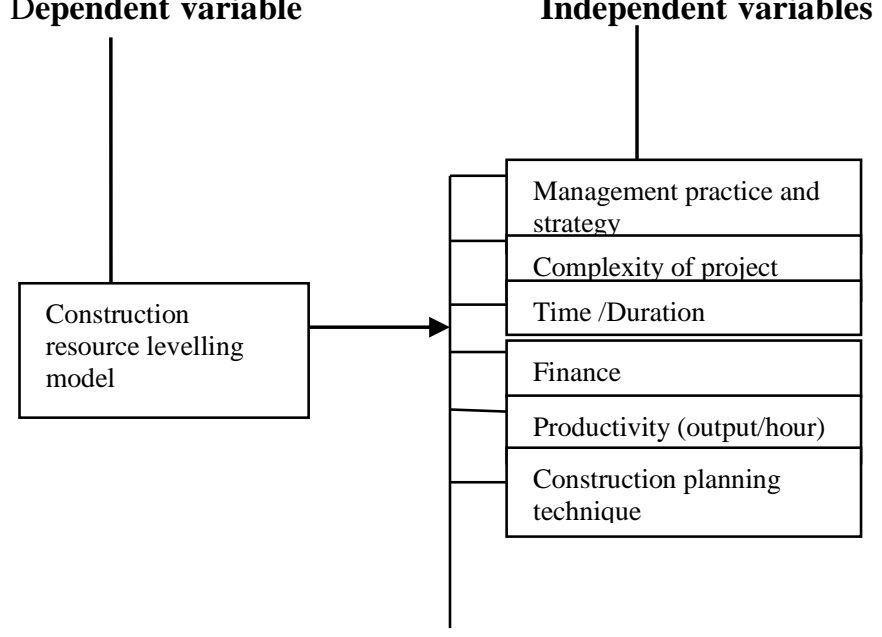

Fig. 1. Conceptual framework

Source: Author, 2017

\section{METHODOLOGY}

\section{A. Research Design}

The research design used in this study was of the explanatory sequential mixed method (Creswell, 2014). The data collection proceeded in two phases with rigorous quantitative data collection and analysis in the first phase, and then followed up with qualitative interviews which helped to explain and confirm the survey responses.

\section{B. Research Method}

Primary data was gathered directly from the site through questionnaires, interview schedules, direct observation and documentary analysis in Nairobi County. The questionnaires comprised of both structured and open ended questions and were administered to contractors and construction managers on live construction sites. Interview schedules were used to obtain in-depth data through face-to- face encounter with senior construction managers in construction firms.

\section{Research Instruments}

Questionnaires were used as the main instrument for collecting data and were complimented with interviews from targeted respondents. Time study forms and multiple activity charts were used for direct recording of observation of studied activities on site. On the other hand since all the information could not be obtained from the field, the researcher supplemented information using secondary data from previous project records, internet, journals articles, periodicals, conference papers and magazines among other

\section{Sampling Method}

For the first phase, Stratified sampling method was used for picking respondents as a clear framework for categories of NCA contractors was readily available from the register of contractors (GOK, 2016). Tromp (2011) argues that for the purpose of generalization of the results findings, a researcher would need a minimum of 30 subjects in each group for corelational and descriptive research. A total of 104 of them participated from the initially targeted 143 subjects. Purposive sampling method was used in the second phase where qualitative data was obtained through interviews.

\section{E. Sampling Method}

In the study, the Relative Importance Index (RII) and statistical package for social sciences (SPSS) version 21 methods were used in the analysis of the data from the field survey on the impacts of resource levelling management practices on the performance of construction firms in Kenya The RII of the identified performance factors were computed using a designed 5-point likert scale as follows:

$$
R I I=\frac{\sum W}{A X N}
$$

Where:

$\mathbf{W}=$ the weight given to each factor by the respondents on a likert scale of 1 to 5

$$
\begin{aligned}
& \mathbf{A}=\text { the highest weight (5) } \\
& \mathbf{N}=\text { the total number of respondents }
\end{aligned}
$$

\section{FINDINGS}

\section{A. Impacts of resource levelling}

The fifteen significant factors which are likely to impact on the performance of construction firms through in-situ concrete practice were obtained from the literature search and were assessed by the respondents. Respondents were asked to rate the importance of the factors and the mean score of each factor was computed. The factors were: implementation of predictive management structure on resource levelling, uniqueness and complexity of the project, duration control mechanism, financial control, productivity output, productivity measurements, economic environment, project documentation and quality performance. Table 1 presents the findings from the respondents' criteria assessment on the rank order of the five most important factors which would impact on enhancement construction project performance on sites in Kenya. 


\begin{tabular}{|c|c|c|c|c|c|c|c|c|c|}
\hline \multicolumn{2}{|c|}{ TABLE I. } & & \multicolumn{7}{|c|}{ IMPACTS OF RESOURCE LEVELLING } \\
\hline \multirow{3}{*}{ Factors } & \multicolumn{5}{|c|}{ Likert Scale } & \multicolumn{4}{|c|}{ Overall } \\
\hline & 1 & 2 & 3 & 4 & 5 & $\Sigma \mathrm{w}$ & $\mathrm{Ax}$ & RII & $\mathrm{Ra}$ \\
\hline & \multicolumn{5}{|c|}{ Frequency of responses } & & $\mathrm{N}$ & & $\mathrm{nk}$ \\
\hline $\begin{array}{l}\text { Incompetent/ } \\
\text { in- } \\
\text { experienced } \\
\text { supervisors }\end{array}$ & 3 & 6 & 3 & 32 & 60 & 452 & 520 & 0.869 & 1 \\
\hline $\begin{array}{l}\text { Lack of } \\
\text { empowerme } \\
\text { nt (training ) }\end{array}$ & 2 & 9 & 7 & 31 & 55 & 440 & 520 & 0.846 & 2 \\
\hline $\begin{array}{l}\text { Lack of } \\
\text { understandin } \\
\mathrm{g} \text { of its } \\
\text { merits }\end{array}$ & 3 & 8 & 17 & 29 & 47 & 421 & 520 & 0.810 & 3 \\
\hline $\begin{array}{l}\text { Work } \\
\text { scheduling }\end{array}$ & 3 & 7 & 16 & 36 & 42 & 419 & 520 & 0.806 & 4 \\
\hline $\begin{array}{l}\text { Strategy } \\
\text { (timely } \\
\text { review of } \\
\text { plans) }\end{array}$ & 0 & 8 & 31 & 25 & 40 & 409 & 520 & 0.787 & 5 \\
\hline
\end{tabular}

Source: Field Survey, 2017

The results from the study show that financial control is the key factor which would impact on the performance of construction firms in Kenya through in-situ concrete practice. When the cash flow for a firm is sound, material and labourforce availability can be guaranteed as the supply of the indicated resources are in abundance in Kenya. Inadequate funds negatively impacts on the implementation of the project since no operation can proceed without sound liquidity. In most cases this would lead to extended contract periods, escalation of claims on interest, loss of profit and increases of cost of resources.

\section{B. Benefits derived from resource levelling}

The ten key benefits which are likely to be derived from the application resource levelling management tools on construction sites were identified from the literature search and were ranked by the respondents in accordance with their level of significance. The benefits were: cost reduction, completion of project on time, optimization of resources, advance planning for future projects increase in productivity, predictive efficiency, improvement in project organizational effectiveness, improvement in quality, supervision, motivation and increase in profitability. Table 2 presents the findings from the respondents' evaluation on the rank order of the five most significant benefits which would impact on construction project performance on site.

TABLE II.

BENEFITS DERIVED FROM RESOURCE LEVELLING

\begin{tabular}{|l|c|c|c|c|c|c|c|c|c|c|}
\hline \multirow{2}{*}{ Benefits } & \multicolumn{7}{|c|}{ Likert Scale } & \multicolumn{4}{c|}{ Overall } \\
\cline { 2 - 10 } & 1 & 2 & 3 & 4 & 5 & $5 \mathrm{~W}$ & $\begin{array}{c}\text { A x } \\
\mathrm{N}\end{array}$ & $\mathrm{RII}$ & $\begin{array}{c}\mathrm{Ra} \\
\mathrm{nk}\end{array}$ \\
\cline { 2 - 10 } & \multicolumn{3}{|c|}{ Frequency of responses } & & & & & \\
\hline $\begin{array}{l}\text { Optimizatio } \\
\text { n of } \\
\text { resources }\end{array}$ & 3 & 6 & 3 & 32 & 60 & 452 & 520 & 0.869 & 1 \\
\hline $\begin{array}{l}\text { Cost } \\
\text { reduction }\end{array}$ & 2 & 9 & 7 & 31 & 55 & 440 & 520 & 0.846 & 2 \\
\hline $\begin{array}{l}\text { Completion } \\
\text { of project } \\
\text { on time }\end{array}$ & 3 & 8 & 17 & 29 & 47 & 421 & 520 & 0.810 & 3 \\
\hline $\begin{array}{l}\text { Advance } \\
\text { planning for } \\
\text { future } \\
\text { projects }\end{array}$ & 3 & 7 & 16 & 36 & 42 & 419 & 520 & 0.806 & 4 \\
\hline $\begin{array}{l}\text { Increase in } \\
\text { productivity }\end{array}$ & 0 & 8 & 31 & 25 & 40 & 409 & 520 & 0.787 & 5 \\
\hline
\end{tabular}

Source: Field Survey, 2017
The results which were analyzed using Relative Importance Index (RII) showed that 'optimization of resources and cost reduction' are the most significant benefits which are derived from the application of resource levelling practice which impacts on construction project performance. The other, key benefits arising from resource levelling highlighted from the study included; completion of project on time, advance planning for future projects and increase in productivity.

\section{Barriers in the application of resource levelling management tools}

The twenty four critical impediments in the application of resource levelling management practices in construction projects which affects construction project performance on site were identified from the literature search and were ranked by the respondents in accordance with their level of severity that each of the impediments would impact on construction project performance on site. The impediments were: lack of empowerment, lack of understanding of its merits, material quality, labour availability, plant/ equipment inadequacy, complexity of project, size of project, scope of project, incompetent/in-experienced supervisors, project time, inadequate project documentation, organization structure in place, work scheduling, occupational health and safety at workplace, site conditions(access, confinement, terrain), quality of performance, credit availability, project cost, economic environment, management practice, delivery mode, strategizing work, the client influence and material compatibility. Table 3 presents the findings from the respondents' evaluation on the rank order of the five most significant impediments in the application of resource levelling management practices which would affect construction project performance on site

TABLE III. BARRIERS IN THE APPLICATION OF RESOURCE

\begin{tabular}{|c|c|c|c|c|c|c|c|c|c|}
\hline & & & W. & . & $90 \mathrm{E}$ & NT T & LS. & & \\
\hline \multirow{3}{*}{ Barriers } & \multicolumn{5}{|c|}{ Likert Scale } & \multicolumn{4}{|c|}{ Overall } \\
\hline & 1 & 2 & 3 & 4 & 5 & $\Sigma \mathrm{w}$ & $\mathrm{Ax}$ & RII & $\mathrm{Ra}$ \\
\hline & \multicolumn{5}{|c|}{ Frequency of responses } & & & & \\
\hline $\begin{array}{l}\text { Incompetent } \\
\text { /in- } \\
\text { experienced } \\
\text { supervisors }\end{array}$ & 3 & 6 & 3 & 32 & 60 & 452 & 520 & 0.869 & 1 \\
\hline $\begin{array}{l}\text { Lack of } \\
\text { empowerme } \\
\text { nt (training) }\end{array}$ & 2 & 9 & 7 & 31 & 55 & 440 & 520 & 0.846 & 2 \\
\hline $\begin{array}{l}\text { Lack of } \\
\text { understandi } \\
\text { ng of its } \\
\text { merits }\end{array}$ & 3 & 8 & 17 & 29 & 47 & 421 & 520 & 0.810 & 3 \\
\hline $\begin{array}{l}\text { Work } \\
\text { scheduling }\end{array}$ & 3 & 7 & 16 & 36 & 42 & 419 & 520 & 0.806 & 4 \\
\hline $\begin{array}{l}\text { Strategy } \\
\text { (timely } \\
\text { review of } \\
\text { plans) }\end{array}$ & 0 & 8 & 31 & 25 & 40 & 409 & 520 & 0.787 & 5 \\
\hline
\end{tabular}

\section{Source: Field Survey, 2017}

The findings in Table 3 indicates that in Kenya, 'incompetent/in-experienced supervisors' is the greatest impediment in the application of resource levelling management practices that affects performance of construction firms in project delivery. It could therefore be argued that the success of construction project performance on site to a great extent depends on the enguity of the site 
supervisor. In-competent supervisor lack the required skills, knowledge and experience to handle the demands of the project in terms of gang sizing, estimating for materials, reduction in wastage and preparing good work programmes. The results from this study is also supported with the findings of the research by Muchungu (2012) who pointed out that the competency of project supervisor contributes significantly to construction project performance.

\section{Predictive performance}

The three potential predictors which contribute towards enhancement of construction resource levelling were obtained from the study findings. Correlation was conducted to examine the relationship between resource levelling and the potential predictors of construction firms' performance. Correlation analysis aimed at determining the strength of the relationship between the factors and construction resource levelling. By using SPSS version 21, the Mean Rank method was applied for the weighting for each of the key predictors of construction firms' performance with regard to resource utilization as indicated in Table 4. Correlation matrix for the predictors is shown in Table 5.

TABLE IV. WEIGHT FACTOR FOR THE FINAL PROJECT PERFORMANCE

\begin{tabular}{|l|c|c|c|c|}
\hline Predictors & $\begin{array}{c}\text { Mean } \\
\text { Rank }\end{array}$ & $\begin{array}{c}\text { Std. } \\
\text { Deviation }\end{array}$ & No & $\begin{array}{c}\text { Corresponding } \\
\text { Weighting }\end{array}$ \\
\hline Finance & 4.5288 & 0.5016 & 104 & 0.338 \\
\hline Optimization & 4.6154 & 0.6582 & 104 & 0.341 \\
\hline Supervisors & 4.3462 & 0.9929 & 104 & 0.321 \\
\hline
\end{tabular}

Source: Author, 2018

\begin{tabular}{|c|l|c|c|c|c|}
\multicolumn{2}{c}{ TABLE V. } & \multicolumn{1}{c|}{ CORRELATION MATRIX } \\
\hline \multirow{2}{*}{} & Finance & $\begin{array}{c}\text { Optimi } \\
\text { zation }\end{array}$ & $\begin{array}{c}\text { Super } \\
\text { visors }\end{array}$ & No \\
\hline \multirow{3}{*}{$\begin{array}{c}\text { Corre } \\
\text { lation }\end{array}$} & Finance & 1.000 & -0.024 & 0.075 & 104 \\
\cline { 2 - 6 } & Optimization & -0.024 & 1.000 & 0.158 & 104 \\
\cline { 2 - 6 } & Supervisors & 0.075 & 0.158 & 1.000 & 104 \\
\hline
\end{tabular}

Source: Author, 2018

* Correlation is significant at the 0.05 level (2-tailed).

The Table 4 reveals that three project success criteria are not highly correlated with each other at $5 \%$ significance level.

\section{E. Proposed resource levelling assessment model}

A model is some form of representation designed to aid in visualizing a thing that cannot be observed directly, either because it has not yet been constructed or because it is abstract (Gwaya, 2015). The construction firms' performance model with regard to resource utilization will be calculated using the following Regression Analysis equation:

$$
\mathrm{CFP}=0.338 \mathrm{FC}+0.341 \mathrm{RO}+0.321 \mathrm{SC} \pm \mathrm{e}
$$

\section{Where:}

$\mathrm{CFP}=$ Construction firms' performance

$\mathrm{FC}=$ Financial control

$\mathrm{RO}=$ Resource optimization

$\mathrm{SC}=$ Supervisors competence

$\mathrm{e}=$ is an error margin of other predictors not in the equation.
All the three predictors of construction firms' performance should be measured based on resources provided for each project by the construction firms.

\section{CONCLUSION}

The paper examined the dynamics of unbalanced uses of resources and pointed out the impediments in the application of resource levelling management practices on performance with regard to resource utilization in construction firms' in Kenya. The study concludes by first observing that financial control, optimization of resource and incompetent/inexperienced supervisors are the factor with the greatest impact on performance. Secondly, the paper proposed a resource levelling assessment model which can be customized and applied in construction projects. The model could be used by construction firms in establishing best practices and standards for resource levelling.

Against such a background, it can be pointed out that supervisory omissions, poor coordination of site activities and failure to synchronize resource availability with project scheduling are some of the factors which construction firms' should guard against if performance on resources utilization is to be improved. The study therefore recommends that construction firms should employ competent supervisors and provide them with continuous training opportunities in the fields of financial control, optimization of resources and best practices on site resource utilization so as to update their knowledge and enhance performance.

\section{REFERENCES}

[1] Badawiyer,B.H.(2010).The effect off planning and resource levelling on UAE Contractors, Dubai: Published MSc.Project Management Thesi, University of Dubai.

[2] Chitkara, K. (2012). Construction project management planning scheduling and controlling. New Delhi: Tata McGraw-Hill.

[3] Creswell, J.W. (2014). Research designs: Qualitative and mixed approaches ( $4^{\text {th }}$ Ed.), London, SAGE

[4] El-Rayes, K., \& Jun, D. H. (2009). Optimizing Resource Levelling in Construction Projects, Journal for Construction Engineering and Management, 135(11), 1172-1180.

[5] Forster, G. (2014). Construction site studies production, administration and personnel. London and New York: Published by Longman.

[6] Galloway, P. D. (2006). "Survey of the construction industry relative to the use of CPM scheduling for construction projects." Journal of Construction Engineering and Management, ASCE, 132(7), 697-711.

[7] Gichunge, H. (2000). Risk Management in The Building Industry in Kenya: Unpublished PhD Thesis. University of Nairobi, Nairobi.

[8] GoK. (2016). NCA, Register of Contractor. Nairobi: Government Press.

[9] Gwaya, A.O. (2015). Development of a project management evaluation model for the construction industry in Kenya. Nairobi: Published PhD Thesis, JKUAT.

[10] Harington, R. (2007). Mitchell's Building construction Structure and Fabric Part 2. London: Prentice Hall.

[11] ILO. (1996-2016). Introduction to Work Study. GENEVA Publications of international labour office.

[12] Inuwa I. I. (2014). Project planning in construction procurement: the case of Nigerian indigenous contractors. Nairobi: Published $\mathrm{PhD}$ Thesis, JKUAT.

[13] KNBS (2016). Kenya National Bureau of statistics (KNBS), Nairobi Government press.

[14] Masu, S. (2006). An Investigation into the causes and impact of Resource mix practices the performance of construction fitms in Kenya. Nairobi: Unpublished PhD Thesis, University of Nairobi.

[15] Mbiti, T. K. (2008). A System Dynamics Model of Construction Output in Kenya, PhD Thesis, School of Property and Construction Project Management. Melbourne, Australia: RMIT University. 
[16] Muchungu, P. (2012). The contribution of human factor in the performance of construction firms in Kenya. Nairobi: Unpublished PhD Thesis, University of Nairobi

[17] PMI. (2015). A guide to the Project Management Body of Knowledge: PMBOK Guide. New York: Project Management Institute.

[18] Talukhaba, A. A. (1999). An investigation into The Factors Causing Construction Project Delays in Kenya. Case Study of High-rise Building Projects in Nairobi. Unpublished PhD. Thesis. University of Nairobi, Nairobi, Kenya.

[19] Tromp, K. (2011). Proposal and Thesis writing an introduction. Nairobi: Pauline publications Africa.

[20] Wanyona, G. (2005). Risk management in the cost planning and control of building projects. The case of Quantity Surveying profession in Kenya. Unpublished PhD Thesis. University of Cape Town., Cape Town, South Africa

\section{AUTHORS PROFILE}

1. Absalom H.V. Lamka

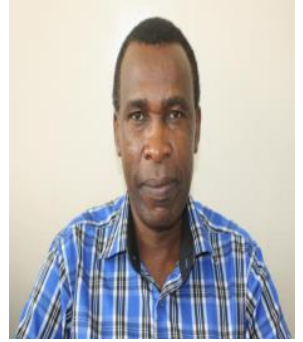

A. Academic Professional Qualification

$\mathrm{PhD}$ (Constn Project Mgt - candidate), TU-K; Master of Constn Project Mgt (JKUAT); B.Phil. Constn Mgt (UoN); Cert Constn Engineering (Polytechnic University, Japan); H/Dip (Constn) Dip. (Bld \& Civil Engineering); M.A.A.K. (CPM-3889); MIET (M/No.1007)

\section{B. Specialization}

Construction Project Management, Construction Contract Documentation, Measurements of building, Measurements of building works, Civil Engineering Measurement and Construction Productivity

\section{Prof. QS. Sylvester Munguti Masu}

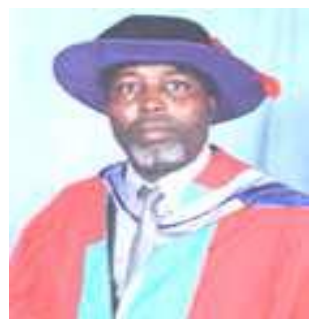

\section{A. Academic Professional Qualification}

$\mathrm{PhD}$ (Constn. Mgt.) UoN; M.A (Bldg. Mgt) UoN; B.A. (Bldg. Econs.) Hons, UoN; M.A.A.K. (Q.S); A.C.I. Arb; F.I.Q.S.K; Registered Q.S, (Q182). F.I.C.P.M (K).

\section{B. Specialization}

Construction Project Management, Construction Contract Documentation, Arbitration and Dispute Resolution, Procurement Management and General Quantity Surveying.

\section{Dr. Wanyona Githae}

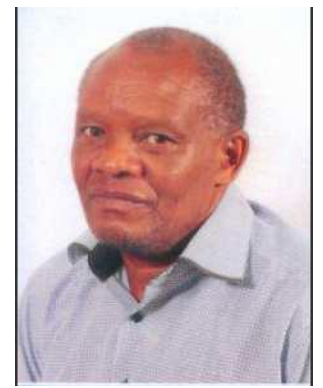

\section{A. Academic Professional Qualification}

$\mathrm{PhD}$ (UCT, South Africa); M. Engineering (Kyoto University, Japan); B.A (Bldg. Econs) UoN; M.A.A.K. (QS-201); Registered Q.S, (CISQK-271).

\section{B. Specialization}

Construction Project Management, Construction Contract Documentation, Project Risk Management, Project Procurement Systems and General Quantity Surveying. 